\title{
Anita, um livro que conta muitos livros
}

Luiz Fernando Ramos*

* Docente da ECA/USP e D outorando na Universidade de São Paulo. 
O romance Anita é uma obra feita a muitas mãos. Bem entendido que o autor, F lávio Aguiar, a escreveu com sua própria pena da primeira à última linha. Mas a matéria de que se serviu nessa escritura, as histórias que desvelou, são narrativas de variadas fontes, fios superpostos e interligados que configuram um conjunto de narradores. Há um narrador que perdeu a condição de centro e passou a disputar com outros a primazia de ser a fonte geradora da ficção. Há uma proliferação de narrativas ao mesmo tempo que, ao final, é uma única história que está sendo contada na justaposição de distintas referências. Aliás, mesmo com essa variedade de focos, a ação se desenvolve com fluência, como uma dança em que parceiros trocassem de pares sem interromper o movimento. A narrativa caminha com rapidez em capítulos curtos e episódicos. Os temas podem ser a descrição minuciosa de paisagens e geografias, as discussões estratégicas das bataIhas que ali se deram, ou a pintura, com tintas apaixonadas, de ações heróicas de personagens históricos com desenlaces surpreendentes. Entre a velocidade do tropel de cavalos em campanhas militares memoráveis e o desenvolvimento paulatino de uma ação principal, tecida com fios originários de fontes as mais díspares, contam-se várias histórias. Entre elas a de A nita G aribaldi, supostamente a personagem central mas, na verdade, sombra que espel ha o verdadeiro protagonista da ação. Este é o mulato Costa, personagem polimorfo que será também Tarquínio, Talco, Teodoro, Sundiata e Assudan, e que escreve um manuscrito contando a história de sua vida ou a história do amor que nutriu por Anita Garibaldi. Mas poderia ser também a história da bisneta do Costa, que se chamou Anita e cuja mãe, Guadalupe, foi quem rescreveu a história do avô a partir de um manuscrito parcialmente queimado. Em vez de somar mais uma voz narrativa às existentes, 
opta-se aqui por não roubar o sabor da surpresa dos futuros leitores resumindo estas histórias, e, apenas, apontar alguns aspectos que recomendam o romance como boa literatura.

Ani ta apresenta um arco de ação marcado pelo episódico e pelo acúmulo de peripécias no estilo das narrativas de Alexandre Dumas. De fato, Costa tinha em Dumas um dos seus modelos literários e é coerente que em sua narrativa procurasse se aproximar desse paradigma. $M$ as sob essa superfície narrativa ligeira, revela-se uma estrutura mais complexa, geradora de leituras abertas a partir da proliferação de narrativas e de narradores, e da fragmentação da trama através de olhares e de pontos de vistas distintos. Há, mesmo, uma admirável autonomia que o romance vai adquirindo à medida que se oferece à leitura, e que o torna independente de seu criador, ou criadores. Estar-se-ia já, nesse caso, no território de ítalo Calvino, e da reverberação de narrativas excêntricas ao narrador. Devese, pois, afinar os olhos para ver o impossível se tornar verossímil, tecido pelo engenho construtivo do autor. Não importa quão fantástica seja a história em foco pois a força do crível se imporá necessariamente. Por isso mesmo, Anita não é um romance histórico. Não só no sentido de não ter sido escrito por um historiador como, também, de que não houve a preocupação de se fazer "História", dando-se conta de um abstrato "o que realmente aconteceu". Pretendeu-se, parece, contar umas boas histórias, e, por obra e graça do prosador, se conseguiu. Há sim precisão histórica, e muitas vezes ela é fundamental para fazer a ação do romance andar. Mas não há, em momento nenhum, um caráter de biografia autorizada, nem sombra de um esmiuçar estéril de detalhes conjunturais. Tudo está como que espelhando uma fábula imaginária e impalpável que se tenta construir, tecer. Certamente, honra-se a máxima aristotélica de que é preferível fazer crer do que ser fiel a fatos e não ser acreditado. Nesse particular, inclusive, reside a grata surpresa do fôlego fabulador de Flávio Aguiar na criação de seu primeiro romance. Não o ameaça, tampouco, a fúria de algum descendente de Anita Garibaldi, pois, mesmo o amor que se sugere tenha florescido entre ela e o Costa manifesta-se, exclusivamente, pelo olhar do segundo. Ele ensinou-a a ler, esteve próximo dela em diversas batalhas e pode assistir a sua morte. $\mathrm{E} m$ todas as ocasiões em que estiveram juntos, mesmo quando dançaram animadamente numa festa, nunca se passou nada que desabonasse a conduta de ambos. O Costa foi sempre um cavalheiro completo e a imorredoura história de amor que cultivou por Anita ao longo de toda vida só concretizou-se em sua imaginação. Se essa paixão também ardeu no coração de Anita é uma incógnita que o romance não se arrisca a solucionar. 0 que existem são indícios como o lenço com as iniciais da heroína, e que ela fez chegar ao Costa e este levou para o túmulo. 
O utro aspecto notável é a construção do personagem do mulato Costa, candidato a marcar uma inflexão na história dos personagens negros da literatura brasileira. O autor informa, no epílogo, que a motivação inicial da empreitada foi a curiosidade sobre um outro personagem lendário das campanhas de Giuseppe Garibaldi no sul do país, no século passado. Trata-se do negro Aguiar, que acompanhou o revolucionário italiano em suas andanças pelo B rasil e E uropa. Foi através da pesquisa sobre Aguiar ( não é um antepassado do autor) que se chegou a Costa e à cópia datilográfica de seu manuscrito. A existência concreta desta narrativa, transmitida não se sabe ao certo por quantos intermediários, se não deixou de oferecer pistas preciosas sobre o negro A guiar, apresentou uma fonte muito mais generosa de informações sobre o mulato Costa. Este também, para todos os efeitos, considerado um negro, narrou sua própria história realçando como o preconceito que sofreu em diversas circunstâncias de sua vida foi uma mola propulsora a definir o seu destino. Nas três vezes em sua vida que Costa ouviu de terceiros a ofensa "negro filho da puta" ele respondeu de forma radical e terminou tendo que recomeçar tudo com novas identidades. Como um negro que nasceu escravo mas nunca foi tratado como tal, que sabia ler desde pequeno, que cresceu como um príncipe na R ecife dos primeiros anos da independência, que cantava e dançava como ninguém, que se tornou um militar de patente com responsabilidades estratégicas, que se fez poliglota e arrebatou corações na Europa do império austro-húngaro, que revolucionou os cafés concertos de Paris e destacou-se no mercado financeiro de $\mathrm{H}$ amburgo, Costa sempre se fez respeitar e foi tratado como igual, contornando os cordões de isolamento do preconceito de cor. Talvez por isso nunca engoliu o tratamento brutal que os escravos brasileiros se acostumaram a receber. $M$ as sua pele era escura e essa marca indelével nunca o livrou dos constrangimentos inerentes a ela. Esse é o ponto que o romance, de forma discreta, destila. Quem olha, narra, pensa e imagina é Costa, não apenas o personagem mas o original, autor verdadeiro da própria história, que escreveu a narrativa depois transformada em romance como uma carta para a neta. $\mathrm{N}$ a intimidade de sua consciência, que revê tudo que ele viveu, o escritor, e depois personagem no romance de Aguiar, vê-se numa posição privilegiada para perceber os limites que os brancos, europeus e brasileiros, têm em relação à sua cor. Principalmente nos episódios passados no Brasil, advém desse ol har de Costa algumas revisões de fatos já sobejamente narrados em outras biografias e romances, como a campanha republicana no R io G rande, que reaparecem de um ponto de vista inédito. Há uma novidade e um frescor na perspectiva do personagem, e por extensão, do autor. A voz culta e vivida de Costa não só revela de forma implacável a ignomínia da escravidão como expressa um profundo desprezo pelos seus agentes e propagadores. O próprio personagem, um herói romântico, vê-se enredado nas armadilhas do 
preconceito, e purga-se da complacência que, em certas ocasiões, conced eu aos brancos racistas. Mas, no final, ele redimirá todas as culpas reagindo como um vingador exemplar num episódio de racismo. Salvo engano, nenhum personagem negro dos romances brasileiros do século dezenove apresentou, jamais, uma tal proeminência e clarividência.

O utro ponto a destacar, e partindo ainda de Costa, é o encantamento a que o personagem submete as mulheres, principais portos da narrativa. Elas demarcam seis das dez partes do livro, sem contar duas partes dedicadas à mãe eà neta. São as mulheres que ele amou e que o amaram que norteiam sua história. São elas que, a cada passo, foram definindo o caminho de sua vida e foram, ao mesmo tempo, tendo suas vidas modificadas por ele. O caso mais candente é o de A nita $G$ aribaldi, que consome especificamente duas partes e reaparece em quase todos os capítulos como uma idéia fixa que nunca abandona o personagem. Com sua "voz aflautada", seus pés de valsa, e seu porte de guerreiro Costa conquistou quase tudo que quis com as mulheres. A única exceção teria sido Anita. Mas se a "quentura daquele olhar" aqueceu para sempre o coração de Costa, seus próprios olhos sedutores talvez tenham tornado cativos os olhares de Anita. É uma leitura possível como a que fazem aqueles que vêem em Capitu olhos cúpidos. $\mathrm{Na}$ verdade, como em M achado, a sedução que o Costa impõe às mulheres estende-se como sedução, através do personagem sedutor, do leitor pelo narrador. Não importa por qual das vozes este narrador se expresse, ele traz o leitor por caminhos sinuosos através de chamarizes atraentes. Sejam peripécias guerreiras, como a que envolve o lance de boleadeira desferido pelo negro Aguiar num combate entre as forças garibaldinas e o exército austro-húngaro na Suiça, que destruiu as têmporas de um oficial austríaco, sejam as amorosas, como os quiproquós envolvendo as amantes de Costa em disputa, em Montevidéu ou em Paris.

Uma última característica marcante em Anita a mencionar é a intensa visualidade do romance, no sentido de se apresentar com aptidões cinematográficas. Como uma câmara plena de mobilidade os olhos do narrador percorrem vastas paisagens e ambientes diminutos, sempre com descrições precisas. E stes olhares perscrutadores aproximam o leitor dos temas e das situações que atendem os interesses do contador da história. É exatamente esta capacidade de focar e recortar ao sabor da finalidade narrativa que aproxima o tratamento da ficção das técnicas de filmagem. M as onde a visualidade está flagrantemente valorizada é na seqüência de quadros e pinturas, que desempenham papel central na formalização de toda a história. Por exemplo, imagens descrevendo a conversão de Santa Taís diante de seu mestre, um escravo núbio, estampadas num livro sobre a vida dos santos que um padre francês, embrenhado na África, deu de presente a N'Dry, a mãe de Costa. Foi com este livro que N'Dry, Costa e Anita aprenderam a ler e a 
escrever. Em outro momento Costa confessa que, diante da impossibilidade de convivência direta com A nita, passou a utilizar todo o seu tempo livre para observála. Esta assiduidade Ihe foi útil mais tarde, em Paris, quando decidiu pintar quadros recriando episódios dramáticos vividos pela amada heroína. Não é possível garantir que ele tenha sido fiel em todos os detalhes, mas algumas das façanhas de Anita Garibaldi foram, além de descritas no romance, visualizadas em telas coloridas que, infelizmente, queimaram num incêndio. A extraordinária história de Costa tem realmente muitas leituras, tantas quantas são escassas as provas de sua veracidade. Mas como trata-se de um verdadeiro romance não há muito a fazer senão relaxar e lê-lo.

\section{R eferências B ibliográficas:}

AGUIAR, Flávio. Anita. São Paulo: B oitempo, 1999. 
